\title{
Using Concordance to Decode the Ideological Weight of Lexis in Learning Narrative Literature: A Computational Approach
}

\author{
Ayman F. Khafaga*1 Iman El-Nabawi Abdel Wahed Shaalan ${ }^{2}$ \\ College of Sciences and Humanities, Prince Sattam bin, Abdulaziz University, Saudi Arabia ${ }^{1,2}$ \\ Faculty of Arts, Suez Canal University, Egypt ${ }^{1}$ \\ College of Humanities, Al-Azhar University, Cairo, Egypt ${ }^{2}$
}

\begin{abstract}
In learning narrative literature, students find difficulty in comprehending and approaching the ideological messages beyond the usage of recurrent lexical items in literary narrative texts. This problem comes as a result of the huge number of lexical items literary texts, particularly the narrative, abound in. The use of the computer and of computational linguistics work makes it possible to process and examine large data for a variety of purposes and to investigate questions that could not feasibly be answered if the analysis was carried manually. This paper, therefore, investigates the relevance of using concordance to decode the ideological weight of lexis in narrative literature. The main objective of the paper is to explore the extent to which certain ideologies and themes are decoded in literary narrative texts undergone a computational concordance analysis. This is conducted by means of a computational concordancing that is intended for providing two verifiable inputs: Frequency Distribution (FD) and Key Word in Context (KWIC). The paper is grounded on an experimental study, where 39 majoring English students attending one novel course at Prince Sattam bin Abdulaziz University, were voluntarily involved in an optional course addressing the study of a narrative literary text: Animal Farm. Participants were divided into two groups: an experimental group and a control group. The former was allowed to use concordance, whereas the latter was only permitted to use conventional methods of studying narrative texts (mere reading). Both groups are assigned to find out the themes and the ideological meanings inferred from a selected list of 13 words from the novel. Results show that the experimental group manages, by applying concordance, to decode the ideological weight of the selected words in a more accurate, credible and faster way than the control group. This in turn facilitates the process of determining the intended message addressed in the novel, either at the character-character level of discourse or at the author-readers one.
\end{abstract}

Keywords-Concordance; computational linguistics; learning; ideology; narrative literature; lexical items

\section{INTRODUCTION}

Introducing digital technologies applications in learning and teaching processes has always been the concern of those who are interested in educational technology [1], [2]. This comes as a result of a vast technological uprising that shapes the different aspects of life, including education. Nowadays, digital devices in general and computers in particular dominate our lives, and this technological domination is

Paper Submission Date: March 31, 2020

Acceptance Notification Date: April 13, 2020

*Corresponding Author expected to continue in the future as long as people with different specializations proceed in targeting an effective communication in foreign languages [3]. Learning English as a foreign language is no exception. This educational field is greatly influenced by the worldwide technological movement [4], [5]. This has clearly been reflected in much literature addressing the use and application of technology in general, and computer software in particular in today's EFL settings [6, $7,8,9,10]$.

The revolution of the use of corpora and of concordance as a tool of the corpus has its significant place within the field of learning and teaching English. This leads text analysts to investigate the effective role played by corpus linguistics in addressing specific topics that, according to O'Keeffe, McCarthy and Carter, include keyword analysis, finding out word frequency counts, cluster analysis, stylistics, translation, lexicography, lexico-grammatical profiles, grammar and concordance [11]. This paper, therefore, focuses on exploring the role of concordance to decode the ideological weight of lexis when learning narrative literature. Concordance is a computational program which enables researchers to find out word-frequency of any text in an accurate and fast way [10].

Three research questions are addressed here: first, how can the ideological significance of lexis be deciphered by means of computational concordancing of literary texts? Second, to what extent does ideological weight of lexis function as indicative in revealing the meanings and themes encoded in literary narrative texts? Third, what are the pedagogical implications beyond the application of concordance in learning narrative texts? The answer of these research questions constitutes the objective targeted in this paper: to explore the extent to which certain ideologies and themes are decoded in literary narrative texts by means of using a computational concordance analysis.

The remainder of this paper is structured as follows. Section 2 reviews the literature, wherein a brief theoretical account on computational linguistics works, instanced by concordance and on lexis as carriers of ideology, is provided. Section 3 offers the methodology of the study, in which corpus and procedures adopted for data analysis are reflected. Section 4 displays the results. Section 5 discusses the results of the study. Section 6 presents the conclusion and offers some suggestions and recommendations for future research. 


\section{LITERATURE REVIEW}

This part presents a brief theoretical account on computational linguistics work (concordance) and a brief account on the importance of lexis as carriers of ideology.

\section{A. Concordance}

Flowerdew defines concordance as "a means of accessing a corpus of text to show how any given word or phrase in the text is used in the immediate contexts in which it appears [12]." Sinclair also postulates that concordance is "a collection of the occurrences of a word -form, each in its own textual environment. In its simplest form, it is an index. Each wordform is indexed, and a reference is given to the place of each occurrence in a text [13]." This program is used for providing analytical clues from the high and/or low frequencies of words. It is also employed to provide collocational analysis of important words in a text, which in turn functions to clarify the ideological significance of these words, either in isolation or in combination of other neighboring words [14].

Thabet states that the computer and the computational linguistics work "have developed applications in automated indexing, cataloguing, concordancing, content and syntactic analysis, and studies of form, of texture, of tone and of rhythm [15]." Kennedy also defines concordance as "a formatted version or display of all the occurrences or tokens of a particular type in a corpus [16]." Kennedy maintains that the type is usually called "a keyword but is sometimes referred to as a target item, node word or search item [16]." Hockey points out that "when each occurrence of each word is presented with the words that surround it, the word index becomes a concordance [17]." This program can "provide information on the company words keep in a corpus," and "can also show different senses of a word type [16]".

The use of computer and a program such as concordance allows for a much thorough and comprehensive study than would otherwise be possible. In this study, concordance is intended for providing two verifiable inputs: Frequency distribution, which refers to the processing option that provides frequency distribution of all lexical items of a text by segment/passage; and, Key word in context (KWIC), which constitutes a processing option that offers all occurrences of any search-word in the text within its contextual environment; that is, the search-word is mentioned accompanied by a number of words which precede and follow it. This option offers "a picture of the environments in which a key word occurs in a corpus [16]." Consequently, concordance programs enable text analysts to produce basic sequences of words through concordance lines, thereby helping them to mark and to arrive at particular tags [18].

The importance of concordance in decoding the ideological significance of words can be found in Widdowson's argument that "a concordance reveals that words will often combine to form commonly occurring phrases which are formulaic in different degrees of fixity and so these combinations too can be taken as having a semantic character [19]." He maintains that concordance is used in text analysis to help arrive at the ideological weight of words as well as their contextual associations. The associations of words also reveal a thematic distribution within texts.
For Higgins, there are two objectives for the use of concordance in the classroom: first, it helps students, by using searching, find out certain words as well as their functional meanings in contexts [20]; and, second, it facilitates the task of students in exploring the particular combination of words, which in turn enables them to identify the significance of these words within their different contextual combinations [21, 22]. Levy [10] further proposes that the learner might use the concordancer in the following ways: checking meaning, checking general syntax, checking usage, exploring special lexis especially ESP vocabulary, checking derived forms, checking collocates of words, and exploring set pieces, e.g. phrasal verbs, clichés.

\section{B. Lexis as Ideology Carriers in Literary Texts}

Fairclough emphasizes the importance of lexis in text analysis. He states that "the structure of a vocabulary is ideologically based [23]," because writers can encode their ideology in vocabulary through wording, meaning relations, metaphor, or euphemism. Writers sometimes use words to communicate ideology to their readers. For him writers might depend on meaning relations to encode ideology in a text. Fairclough [23] points out that the main meaning relations are "synonymy, hyponymy, and antonymy." Synonymy "is the case where words have the same meaning"; hyponymy "is the case where the meaning of one word is, so to speak, included within the meaning of another word." For example, the meaning of the word 'totalitarianism' can be included in the meaning of 'communism' or 'Marxism'; and antonymy 'is meaning incompatible- the meaning of one word is incompatible with the meaning of another." Fairclough and Fairclough state that "meaning relations like synonymy can often be regarded as relative to particular ideologies; either the ideology embedded in a discourse type or the ideology being creatively generated in a text [24]."

\section{MethodOLOGY}

\section{A. Corpus}

The corpus consists of one selected novel written by George Orwell in 1944: Animal Farm. The reason why this novel is chosen in particular lies in the fact that it is recurrently authorized as one part of a course entitled 'Novel in the Twentieth Century' which is dedicated to level-seven students majoring English at the department of English, Prince Sattam University, Saudi Arabia. The selected novel is subjected to the text analysis computer program: concordance, through which two options are used: Frequency Distribution Analysis (FDA) and Key Word in Context (KWIC).

\section{B. Animal Farm: The Story}

Bolton considers this novel the book that highlights the literary singularity and the international popularity of Orwell [25]. The episodes of Animal Farm [26] can be divided into two parts: the part before the rebellion and the part after it. Discursively, the first part is described as a discourse of equality, whereas the second part is perceived as a discourse of inequality. In the discourse of equality, the animals are united to get rid of man, the symbol of their slavery and the cause of the hardships they lead. The animals managed to remove man from the farm and lay down some principles that 
intended to raise the banner of equality among all animals, no superiority of one animal over another, and all work for the sake of the farm and not to let man, represented in Mr. Jones, be back again to rule the farm. The discourse of inequality witnesses a shift in discourse and a change in behavior. The pigs come to have more privileges than the other animals. This is conducted under the pretext that they (pigs) are the brain workers whose ability to think to secure the farm from man should be met by singularity over other animals. All principles put during the discourse of equality have come to be altered one after another till there only one principle left: all animals are equal but some animals are more equal than others. The ultimate result is that pigs replaced man in the farm by dominating other animals and controlling their actions.

\section{Procedure}

The methodological procedure adopted in this paper constitutes three stages. In the first stage, the selected novel has been electronically scanned, stored, and analyzed using 'concordance'; a computational program which enables researchers (learners) to find out word-frequency of any text in an accurate and fast way. In the second stage, 13 words were intentionally selected and indicatively highlighted as carrying ideological and thematic significance in the novel under investigation. These words are: man, rebellion, remains, miserable, slavery, free, leader, sacrifice, criminal, traitor, tactics, equal, and brothers. These words are given to the two groups of learners to decode the implied ideologies they carry, either by means of using concordance (experimental group) or through conventional methods of reading (control group). The third stage encompasses a thematic and ideological analysis to the selected words. The focus in this stage is on the process of decoding the implied meanings and ideologies these words communicate, either by an observation to their frequency analysis or by the company of words they have (their contextual environment in text).

The paper is grounded on an experimental study, where 39 majoring English students attending one novel course at Prince Sattam bin Abdulaziz University, were voluntarily involved in an optional course addressing the study of a narrative literary text: Animal Farm. Participants were divided into two groups: an experimental group and a control group. The former was allowed to use concordance, whereas the latter was only permitted to use conventional methods of studying narrative texts (mere reading). Both groups were assigned to find out the themes and the ideological meanings conveyed by the selected 13- words list from the novel.

Significantly, the thematic analysis of the ideological and thematic weight of the selected words can be done by a thematic distribution of any search-word according to its contextual environment. The reason why concordance is particularly selected lies in Hockey's words that "the production of word indexes and concordances is the most obvious application of the computer in literary research [17]." He emphasizes that such an automated approach to text analysis provides "a basis for decisions on the various linguistic aspects of vocabulary expression, morphological, syntactic, and semantic dimensions of contained data, and the presentation of lexical and syntactic items and collocations of both high and low frequency [17]."
The two groups were involved in a pre-process task and an in-process task. In the pre-process task, both groups attended 3 classroom sessions, each lasted for 3 hours, wherein they were acquainted with a list of 13 words that were deliberately selected from the novel under investigation; they were told of the significance of these words; and they were taught how these words play a significantly indicative role in communicating certain meanings and themes in the novel. Both groups were guaranteed that they both were totally familiar with the ideological weight pertaining to each word from the selected list. Afterwards, the in-process task started, by separating the two groups and allocating each group one particular task. The experimental group was allowed to use the concordance program to show the ideologies each word of the list carries and to arrive at the themes addressed by these words. The control group was assigned the same task of the experimental one, yet it was not allowed to use the concordance program. They were only allowed to use traditional methods of studying a novel; that is, by means of reading the text. Importantly, both groups were informed that they should decode the ideologies of the given list of words, as well as the thematic significance of each one by means of showing the number of occurrences of each word in the novel and the company of words each word keeps in context. The inprocess task lasted for two weeks. Tables I and II offer a description of the participants' data and the learning tasks allocated for each group.

TABLE I. DESCRIPTION OF PARTICIPANTS DATA

\begin{tabular}{|l|l|l|}
\hline Description & Experimental group & Control group \\
\hline Number & 19 & 20 \\
\hline Age & From 20 to 23 & From 20 to 23 \\
\hline Gender & Male & Male \\
\hline Nationality & Saudi & Saudi \\
\hline Course title & Novel in the $20^{\text {th }}$ century & Novel in the $20^{\text {th }}$ century \\
\hline Academic Level & 7 & 7 \\
\hline University & $\begin{array}{l}\text { Prince Sattam bin Abdelaziz } \\
\text { University }\end{array}$ & $\begin{array}{l}\text { Prince Sattam bin } \\
\text { Abdelaziz University }\end{array}$ \\
\hline
\end{tabular}

TABLE II. DESCRIPTION OF ALLOCATED TASKS

\begin{tabular}{|c|c|c|}
\hline Description & Experimental group & Control group \\
\hline $\begin{array}{l}\text { Pre-process } \\
\text { task }\end{array}$ & $\begin{array}{l}\text {-Attended the same } \\
\text { classroom. } \\
\text {-Provided with the } 13 \text {-word } \\
\text { list. } \\
\text {-Academically familiarized } \\
\text { with the ideological and } \\
\text { thematic importance of the } \\
\text { selected word list. }\end{array}$ & $\begin{array}{l}\text {-Attended the same } \\
\text { classroom. } \\
\text {-Provided with the 13-word } \\
\text { list. } \\
\text {-Academically familiarized } \\
\text { with the ideological and } \\
\text { thematic importance of the } \\
\text { selected word list. }\end{array}$ \\
\hline $\begin{array}{l}\text { In-process } \\
\text { task }\end{array}$ & $\begin{array}{l}\text {-Decoding the ideologies } \\
\text { pertaining to each word. } \\
\text {-Highlighting the thematic } \\
\text { significance of each word. }\end{array}$ & $\begin{array}{l}\text {-Decoding the ideologies } \\
\text { pertaining to each word. } \\
\text {-Highlighting the thematic } \\
\text { significance of each word. }\end{array}$ \\
\hline $\begin{array}{l}\text { Method of } \\
\text { learning }\end{array}$ & $\begin{array}{l}\text {-Technologically-based } \\
\text { (using concordance) }\end{array}$ & $\begin{array}{l}\text {-Traditionally-based (mere } \\
\text { act of reading/manual) }\end{array}$ \\
\hline
\end{tabular}




\section{RESUlTS}

This part displays the results arrived at by both the experimental group and the control group in their attempt to decode the ideological and thematic significance of the selected 13-words list.

\section{A. Experimental Group: Technologically-based on Concordance}

This section reports a number of results to the selected list of words under investigation. The computational analysis covers two variables: the frequency distribution and the contextual environment of the selected words. Significantly, the results in the following computational analyses are arrived at by the majority of the participants in the experiment group and with nearly the same accuracy, either in terms of the total frequency (FT) pertaining to each lexis or in terms of the contextual nature of the word, i.e. its position among neighboring words. Table III summarizes the results obtained by the experimental group during the in-process task (for more clarifications, see Tables I-XIII in the Appendix).

Table III clarifies that in targeting the total frequencies of the selected words, all participants managed to provide the right total frequency attributed to 11 words out of 13 , whereas only 3 participants failed to arrive at the right frequency for the lexis rebellion, and 1 participant failed to provide the proper frequency for the lexis sacrifice. This indicates the very high accuracy concordance offers EFL learners in pursuing the different educational purposes they are assigned to.

\section{B. Control Group: Traditionally-based Analysis}

This section demonstrates the results arrived at by the participants in the control group. The analysis of the novel adopted by this group, as alluded before, is based on the traditional method of learning, i.e. merely by reading (manually). Crucially, the results reported by almost all the participants in this group exhibited discrepancy from one participant to another. Consider the following table.

TABLE III. EXPERIMENTAL GROUP RESPONSES TO IN-PROCESS TASK

\begin{tabular}{|l|l|l|l|l|}
\hline $\begin{array}{l}\text { Lexical } \\
\text { item }\end{array}$ & $\begin{array}{l}\text { Actual No. } \\
\text { of total } \\
\text { frequency }\end{array}$ & $\begin{array}{l}\text { Maximum } \\
\text { No. of } \\
\text { agreement } \\
\text { among } \\
\text { participants }\end{array}$ & $\begin{array}{l}\text { Actual No. of } \\
\text { indicative } \\
\text { occurrences }\end{array}$ & $\begin{array}{l}\text { Maximum } \\
\text { No. of } \\
\text { agreement } \\
\text { among } \\
\text { participants }\end{array}$ \\
\hline Man & 21 & 19 & 11 & 16 \\
\hline Rebellion & 29 & 16 & 2 & 16 \\
\hline Remains & 1 & 19 & 1 & 19 \\
\hline Miserable & 5 & 19 & 3 & 18 \\
\hline Slavery & 3 & 19 & 1 & 19 \\
\hline Free & 7 & 19 & 1 & 19 \\
\hline Leader & 8 & 19 & 5 & 17 \\
\hline Sacrifice & 4 & 18 & 2 & 16 \\
\hline Criminal & 1 & 19 & 1 & 19 \\
\hline Traitor & 3 & 19 & 2 & 18 \\
\hline Tactics & 2 & 19 & 2 & 19 \\
\hline Equal & 8 & 19 & 2 & 16 \\
\hline Brothers & 1 & 19 & 1 & 19 \\
\hline
\end{tabular}

TABLE IV. CONTROL GROUP RESPONSES TO IN-PROCESS TASK

\begin{tabular}{|l|l|l|l|l|}
\hline $\begin{array}{l}\text { Lexical } \\
\text { item }\end{array}$ & $\begin{array}{l}\text { Actual No. } \\
\text { of Total } \\
\text { Frequency }\end{array}$ & $\begin{array}{l}\text { Maximum } \\
\text { No. of } \\
\text { agreement } \\
\text { among } \\
\text { participants }\end{array}$ & $\begin{array}{l}\text { Actual No. of } \\
\text { Indicative } \\
\text { Occurrences }\end{array}$ & $\begin{array}{l}\text { Maximum } \\
\text { No. of } \\
\text { agreement } \\
\text { among } \\
\text { participants }\end{array}$ \\
\hline Man & 21 & 3 & 11 & 2 \\
\hline Rebellion & 29 & 4 & 2 & 0 \\
\hline Remains & 1 & 0 & 1 & 0 \\
\hline Miserable & 5 & 2 & 3 & 0 \\
\hline Slavery & 3 & 2 & 1 & 2 \\
\hline Free & 7 & 3 & 1 & 0 \\
\hline Leader & 8 & 3 & 5 & 2 \\
\hline Sacrifice & 4 & 2 & 2 & 0 \\
\hline Criminal & 1 & 4 & 1 & 4 \\
\hline Traitor & 3 & 4 & 2 & 2 \\
\hline Tactics & 2 & 5 & 2 & 3 \\
\hline Equal & 8 & 3 & 2 & 2 \\
\hline Brothers & 1 & 5 & 1 & 5 \\
\hline
\end{tabular}

As indicated in Table IV, few participants have come to be in conformity with each other in terms of either the total number of occurrences each word has, or with regard to the number and the context of the indicative occurrences each selected lexis displays. The indication of this discrepancy among participants will be reflected in the discussion section below.

\section{DISCUSSION}

The above results indicate that there is a clear difference between the responses of the two groups in terms of the inprocess task. The use of the computational analysis by means of using the program of concordance on the part of the experimental group enables the participants to arrive at very accurate, fast and credible results concerning the total frequency of the words under investigation and in terms of the thematic significance of these words. With the help of concordance, the participants in the experimental group managed not only to register the total frequency for each lexical item, but they also succeeded in highlighting the indicative occurrences out of the total frequency of each word. Crucially, concordance provided them with both accuracy and credibility upon which they can build their own interpretations concerning thematic significance pertaining to each word.

The control group, on the other hand, failed to provide an accurate or credible frequency distribution for the selected list of words. Results demonstrated that no one of the participants in this group managed to provide the right total frequency pertaining to each word. They also failed to mark the indicative occurrences out of the total frequency of each word. This group also displayed discrepancies among each other; that is, they are different in terms of the number of occurrences as well as the indicative ones. The highest number of agreement among participants was 5, and it was recorded for only two lexical items, tactics and brothers. Furthermore, almost all participants in the control group did not manage to determine the most indicative occurrences of the selected words. 
The implication here is that the use of technology, instanced by concordance, helps advance and develop the process of learning. Significantly, the introduction of technology in the process of learning has always been the concern of many scholars who are interested in incorporating modern technology in the process of learning in general, and in learning English in particular [27, 28, 29, 30, 31]. Integrating technology into education has become an urgent need and a necessity on the part of both teachers and learners, which in turn functions to raise the need for more software, particularly in the learning process to facilitate the task of getting knowledge on the part of learners [32]. The use of concordance also proved to be enjoyable on the part of the participants in the experimental group. In this regard, Johns [33] argued that by using concordance students became a linguistic researcher that enjoys exploring the ideological meanings of the target word in a real context. Participants expressed their agreement that they enjoyed the use of concordance as a tool in learning narrative literature. This is also emphasized by Gavioli [34] who stated that with the passage of time, students get accustomed to the use of concordance as an enjoyable activity in the process of leaning.

The traditional method allowed to the control group during the in-process task has proved useless, inaccurate and inadequate in the learning process, particularly if learners come to study narrative literary texts as is the case for the novel selected for the current research purpose. Conventional methods of learning are no longer suitable for learning or teaching narrative texts. Within the atmosphere of information technology revolution the world witnesses today, there is no place for the old traditional methods of learning. The application of computer to the different literary courses at Saudi universities should be considered from not only an academic perspective, but also from a professional one in a way that prepares graduates for the recent requirements of today's labor market $[21,35]$.

Further, the use of concordance enabled the experimental group to classify the 13 -word list into two groups pertaining to two types of discourse employed in the selected novel: the discourse of equality, which dominates the first part of the novel; and the discourse of inequality that shapes the second part of the novel. Participants agreed that the words man, rebellion, miserable, slavery, free, brothers and equally are attributed to the discourse of equality, in which these words are dexterously employed to persuade the animals to get rid of the rule of Man represented in Mr. Jones, and to rule the whole farm by themselves. Participants also were in conformity with the result that the words remains, leader, sacrifice, criminal, traitor and tactics are affiliated to the discourse of inequality, and have been utilized by the pigs to manipulate the other animals into complete compliance to the rule of Napoleon, their new ruler. Significantly, this classification of words as well as of discourse types on the part of the experimental group indicates that participants of this group greatly benefited from concordance to categorize the 13-words list according to the types of discourse used in the novel. This, for them, was conducted by the analysis of the key word in context (KWIC) offered by concordance (see Appendix).
In light of concordance, the experimental group has come to the conclusion that not only high frequency words are indicative in the thematic significance, but also words of low frequency distribution are of great importance in communicating certain ideologies and themes. For example, members of this group postulated that the words remains, slavery, criminal, traitor, tactics and brothers, however, very low in frequency, they are highly indicative in conveying the ideologies of euphemism, manipulation and motivating a revolutionary act in the discourse of the novel under investigation (see Tables III, V, IX, X, XI, XIII in the Appendix, respectively). Additionally, participants of the experimental group further managed to highlight the indicative occurrences among the total frequencies of the high frequency words. This also enabled them to decode the thematic significance of the selected words. For example, they emphasized that the two words man and rebellion have been recorded as the highest frequent words in the selected list (21 and 29 occurrences, respectively), however, only 11 occurrences for man and 2 occurrences for rebellion have been marked as highly indicative in motivating the animals towards a revolution against the rule of $\mathrm{Mr}$. Jones, taking into consideration the allegorical nature of the novel (see Tables I, II in the Appendix).

\section{CONCLUSION}

This study attempted to explore the role of concordance in learning narrative literary texts. The study aimed to show whether or not the use of concordance as a learning tool has an impact on the performance of learners dedicated to learning narrative literary texts in an EFL setting. The study was mainly an experimental one, so, it involved two groups of students conveniently: an experimental group and a control group. The experimental group was exposed to electronic concordance program, whereas the control group was only allowed to use traditional method of learning. The study clarified that the group that applied concordance to the analysis of the selected novel performed the allocated task much more accurate and faster than the control group, which was only permitted a traditional learning methods. The study revealed that concordance proved to be influentially significant in learning narrative literary texts since it facilities the task of understanding the ideological meanings words encode in texts. This has linguistically been evidenced via the quantitative and the qualitative results.

The study further clarified that the use of concordance in EFL settings, with the data authenticity it provides learners with, functions to enhance the active participation and motivation towards the study of literary narratives, and also helps learners execute their academic tasks in an accurate and credible way, as well as in a very short period of time. The study demonstrated that applying concordance in the literary classes stimulates enquiry and speculation on the part of learners. It helps them to achieve independence in the process of learning. Crucially, the use and application of concordance provide authentic materials not only for learners but also for teachers.

Finally, for future research, this paper recommends further extensive studies on the impact and significance of using and 
applying concordance on the process of learning in general, and on approaching the literary narrative texts in particular. This might reveal similar and/or different results other than what is reported in the current study. Also recommended is a study on the availability of applying concordance to the process of teaching and learning other university literary courses (e.g., drama courses, criticism courses and poetry courses) that need such type of technology due to the enormous number of pages and lexis these texts contain.

\section{ACKNOWLEDGMENT}

This publication was supported by the Deanship of Scientific Research at Prince Sattam bin Abdulaziz University, Alkharj, Saudi Arabia.

\section{REFERENCES}

[1] L. Pedro, C. Barbosa, and C. Santos, "A critical review of mobile learning integration in formal educational contexts," International Journal of Educational Technology in Higher Education, vol.15, no. 1, 2018. https://doi.org/10.1186/s41239-018-0091-4.

[2] M. Eltahir, S. Al-Qatawneh, and S. Alsalhi, "E-Textbooks and their application levels, from the perspective of faculty members at Ajman University, U.A.E," International Journal of Emerging Technologies in Learning, vol. 14, no. 13, pp. 88-104, 2019. https://doi.org/10.3991/ijet.v14i13.9489.

[3] J. Poushter, "Smartphone ownership and internet usage continues to clim in emerging economies. Washington> Pew Research Center, 2016. Retrieved from http://www. pewglobal.org. smartphone-ownership-andinternet-usage-continues-to-climbin- emerging economies/ [Accessed: Sep. 23, 2019].

[4] Y. Karpenko, "Multimedia computer software for the professional training of prospective specialists in foreign languages for preschool and primary education. Information Technologies and Learning Tools, vol. 57, no. 1, pp. 50-55, 2017.

[5] Y. Zhang, and L. Zuo, "College English teaching status and individualized teaching design in the context of mobile learning," International Journal of Emerging Technologies in Learning, vol. 14, no. 12, pp. 85-96, 2019. https://doi.org/10.3991/ijet.v14i12.10704.

[6] T. Xuemei, "Concordance-based learning and teaching of grammar," The 6th International Conference on Computer Science \& Education (ICCSE 2011) August 3-5, 2011. SuperStar Virgo, Singapore, PP. 12391242. https://doi.org/10.1109/ICCSE.2011.6028856.

[7] E. Y1lmaz, and \&A. Soruç, "The use of concordance for teaching vocabulary: A data-driven learning approach," Procedia - Social and Behavioral Sciences, vol. 191, pp. 2626 -2630, 2015. https://doi.org/10.1016/j.sbspro.2015.04.400.

[8] D. Sari, "measuring quality of reading materials in English textbook: the use of lexical density method in assessing complexity of reading materials of Indonesia's curriculum-13(k 13) English textbook," Journal of Applied Linguistics and Literature, vol. 2, no. 2, pp. 30-39, Dec. 2016. https://doi.org/10.33369/joall.v1i2.4177.

[9] J. Butler, J. "Cloze procedures and concordances: the advantages of discourse level authenticity in testing expectancy grammar," System, vol. 19, no. 1-2, pp. 29-38, 1991. https://doi.org/10.1016/0346251X(91)90005-A.

[10] M. Levy, "Concordances and their integration into a word-processing environment for language learners," System, vol.18, no. 2, pp. 177-188, 1990. https://doi.org/10.1016/0346-251X(90)90052-7.

[11] A. O'Keeffe, M. McCarthy, and R. Carter, From Corpus to Classroom. Cambridge: Cambridge University Press, 2007. https://doi.org/10.1017/CBO9780511497650.

[12] J. Flowerdew, "Concordancing as a tool in course design," System, vol. 21 , no. 2, pp. 231-244, 1993. https://doi.org/10.1016/0346$251 \mathrm{X}(93) 90044-\mathrm{H}$.

[13] J. Sinclair, Corpus, Concordance Collocation. Oxford: Oxford University Press, 1991.
[14] B. Kettemann, "On the use of concordancing in ELT," TELL \& CALL, vol. 4, pp. 4-15, 1995.

[15] A. Thabet, "Applied computational linguistics: an approach to analysis and evaluation of EFL materials," Damietta Faculty of Education Journal, Part 1, No. 13, pp. 7-39, 1990.

[16] G. Kennedy, An Introduction to Corpus Linguistics. London \& New York: Longman, 1998.

[17] S. Hockey, A Guide to Computer Applications in the Humanities. London: The Johns Hopkins University Press, 1980.

[18] C. F. Meyer, English Corpus Linguistics: An Introduction. Cambridge: Cambridge University Press, 2004.

[19] H.G. Widdowson, Text, Context, Pretext: Critical Issues in Discourse Analysis. Blackwell Publication, 2004. https://doi.org/10.1002/9780470758427.

[20] J. Higgins, "Which concordancers: a comparative review of MSDOS software," System, vol.19, no. 1/2, pp. 91-100, 1991. https://doi.org/10.1016/0346-251X(91)90010-M.

[21] N. Dwivedi, Exploring Institutional Logics for Technology-Mediated Higher Education. Taylor \& Francis, 2019. https://doi.org/10.4324/9780429486135.

[22] C. Tribble, "Concordancing and an EAP writing programme," CAELL Journal, vol. 1, no. 2, pp. 10-15, 1990.

[23] N. Fairclough, Language and Power. London \& New York: Longman, 1989.

[24] N. Fairclough, and I. Fairclough, Political Discourse Analysis: A Method for Advanced Students. Routledge, 2012. https://doi.org/10.4324/9780203137888.

[25] W. F. Bolton, The Language of 1984. Orwell's English and Ours. Basil Blackwell Publisher Limited, 1984.

[26] G. Orwell, Animal Farm. Penguin Books Ltd, 1979.

[27] M. Henderson, M. J. Henderson, and G. Romeo, Teaching and Digital Technologies: Big Issues and Critical Questions. Cambridge University Press, 2015.

[28] A. Picciano, Online Education: Foundations, Planning, and Pedagogy. Taylor \& Francis, 2017. https://doi.org/10.4324/9781315226750.

[29] F. Farr and L. Murray, The Routledge Handbook of Language Learning and Technology. Taylor \& Francis, 2016. https://doi.org/10.4324/9781315657899.

[30] M. Muhamad and G. H. Seng, "Teachers' perspective of 21st century learning skills in Malaysian ESL classrooms," international Journal of Advanced and Applied Sciences, vol. 6, no. 10, pp. 32-37, 2019. https://doi.org/10.21833/ijaas.2019.10.006.

[31] W. Gong, "An innovative English teaching system based on computer aided technology and corpus management," international Journal of Emerging Technologies in Learning, vol. 14, no. 14, pp. 69-80, 2019. https://doi.org/10.3991/ijet.v14i14.10817.

[32] R. M. Baecker, Computers and Society: Modern Perspectives. Oxford University Press, 2019.

[33] T. Johns, "Data-driven learning: the perpetual challenge," in B. Kettemann, and G, Marko (Eds.), Teaching and Learning by Doing Corpus Linguistics, pp. 107-117. Amsterdam: Rodopi, 2002. https://doi.org/10.1163/9789004334236_010.

[34] L. Gavioli, "Exploring texts through the concordancer: Guiding the learner," in A. Wichmann, S. Fligelstone, T. McEnery, and G. Knowles (Eds.), Teaching and Language Corpora, pp. 83-99. London: Longman, 1997. https://doi.org/10.4324/9781315842677-8.

[35] L. Zhang, "Study on the application of web information retrieval in the teaching of language translation," International Journal of Emerging Technologies in Learning, vol. 11, no. 4, pp. 14-119, 2016. https://doi.org/10.3991/ijet.v11i04.5550.

\section{APPENDIX}

The following tables (Tables I-XIII) demonstrate the frequency distribution analysis (FDA) and the key word in context (KWIC) of the 13word list of the study, against which the results of the two groups (experimental and control) are compared. Only indicative occurrences out of the total frequency of each word are recorded in the tables. 
TABLE. I. CONCORDANCE OF 'MAN'

\begin{tabular}{|l|l|l|l|}
\hline MAN...........................TF (21) & word & Context & Line \\
\hline Context & Man & is the only real enemy & 79 \\
\hline up in a single word-Man. & Man & from the scene, and the & 79 \\
\hline $\begin{array}{l}\text { real enemy we have. } \\
\text { Remove }\end{array}$ & Man & Is the only creature that & \\
\hline $\begin{array}{l}\text { Overwork is abolished } \\
\text { forever. }\end{array}$ & Man & , and the produce of our & 107 \\
\hline beings? Only get rid of & Man & and the animals have a & 117 \\
\hline when they tell you that & Man & Serves the interests of no & 118 \\
\hline others. It is all lies. & Man & and all his ways. Whatever & 133 \\
\hline your duty of enmity towards & Man & , we must not come to & 135 \\
\hline also that in fighting against & Man & are evil. And, above all & 138 \\
\hline trade. All the habits of & Man & has vanished. & 142 \\
\hline as it will be when & Man & $\begin{array}{l}\text { shall be o'erthrown, And } \\
\text { the }\end{array}$ & 160 \\
\hline the day is coming, Tyrant & \multicolumn{3}{|c}{ Note: TF - means total frequency } \\
\hline
\end{tabular}

TABLE. II. CONCORDANCE OF 'REBELLION'

\begin{tabular}{|c|c|c|c|}
\hline \multicolumn{4}{|c|}{ REBELLION.........................TF (29) } \\
\hline Context & word & context & line \\
\hline $\begin{array}{l}\text { My message to you, } \\
\text { comrades: }\end{array}$ & Rebellion & ! I do not know when & 14 \\
\hline do not know when that & Rebellion & $\begin{array}{l}\text { will come, it might } \\
\text { be }\end{array}$ & 14 \\
\hline
\end{tabular}

TABLE. III. CONCORDANCE OF 'REMAINS'

\begin{tabular}{|c|c|c|c|}
\hline \multicolumn{4}{|c|}{ REMAINS.......................TF (1) } \\
\hline Context & word & context & line \\
\hline $\begin{array}{l}\text { bring back their lamented } \\
\text { comrade's }\end{array}$ & Remains & $\begin{array}{l}\text { for interment on } \\
\text { the farm }\end{array}$ & 312 \\
\hline
\end{tabular}

TABLE. IV. CONCORDANCE OF 'Miserable'

\begin{tabular}{|c|c|c|c|}
\hline \multicolumn{4}{|c|}{ MISERABLE.......................TF (5) } \\
\hline context & word & context & line \\
\hline our lives are & miserable & , laborious, and short. & 10 \\
\hline do we continue in this & miserable & $\begin{array}{l}\text { condition? Because } \\
\text { nearly the }\end{array}$ & 11 \\
\hline And even the & miserable & lives we lead are not & 13 \\
\hline
\end{tabular}

TABLE. V. CONCORDANCE OF 'SLAVERY'

\begin{tabular}{|l|l|l|l|}
\hline \multicolumn{3}{|l|}{ SLAVERY......................TF (3) } & context \\
\hline context & Word & $\begin{array}{l}\text { : that is the plain } \\
\text { truth }\end{array}$ & 10 \\
\hline $\begin{array}{l}\text { an animal is misery } \\
\text { and }\end{array}$ & Slavery &
\end{tabular}

TABLE. VI. CONCORDANCE OF 'FREE'

\begin{tabular}{|l|l|l|l|}
\hline \multicolumn{2}{|l|}{ FREE..........................TF (7) } & context & line \\
\hline Context & Word & $\begin{array}{l}\text { What then must } \\
\text { we do }\end{array}$ & 14 \\
\hline we could become rich and & Free &
\end{tabular}

TABLE. VII. CONCORDANCE OF 'LEADER'

\begin{tabular}{|l|l|l|l|}
\hline \multicolumn{4}{|l|}{ LEADER..........................TF (8) } \\
\hline Context & word & context & line \\
\hline not been for our heroic & Leader & $\begin{array}{l}\text {, Comrade Napoleon. } \\
\text { Do you }\end{array}$ & 195 \\
\hline a good comrade." "Our & Leader & , Comrade Napoleon," & 198 \\
\hline in formal style as "our & Leader & $\begin{array}{l}\text {, Comrade Napoleon," } \\
\text { and this }\end{array}$ & 224 \\
\hline "Under the guidance of our & Leader & $\begin{array}{l}\text {, Comrade Napoleon, I } \\
\text { have }\end{array}$ & 224 \\
\hline they knew their beloved & Leader & $\begin{array}{l}\text { Comrade Napoleon, } \\
\text { better }\end{array}$ & 310 \\
\hline
\end{tabular}

TABLE. VIII. CONCORDANCE OF 'SACRIFICE'

\begin{tabular}{|l|l|l|l|}
\hline SACRIFICE.....................TF (4) & context & line \\
\hline Context & word & cont & 146 \\
\hline $\begin{array}{l}\text { every animal here } \\
\text { appreciates the }\end{array}$ & Sacrifice & $\begin{array}{l}\text { that Comrade Napoleon } \\
\text { has made }\end{array}$ & 160 \\
\hline $\begin{array}{l}\text { Napoleon, should } \\
\text { welcome this }\end{array}$ & Sacrifice & $\begin{array}{l}\text { as their own special } \\
\text { contribution }\end{array}$ & \\
\hline
\end{tabular}

TABLE. IX. CONCORDANCE OF 'CRIMINAL'

\begin{tabular}{|l|l|l|l|}
\hline CRIMINAL.......................TF (1) & context & line \\
\hline context & word & $\begin{array}{l}\text { ?" "He fought bravely } \\
\text { at }\end{array}$ & 146 \\
\hline was no better than a & criminal &
\end{tabular}

TABLE. X. CONCORdANCE OF 'TRAITOR'

\begin{tabular}{|l|l|l|l|}
\hline TRAITOR......................TF (3) & word & context & line \\
\hline $\begin{array}{l}\text { fontext } \\
\text { expulsion, this }\end{array}$ & traitor & $\begin{array}{l}\text { has crept here under } \\
\text { cover }\end{array}$ & 174 \\
\hline We will teach this miserable & traitor & that he cannot undo our & 176 \\
\hline
\end{tabular}

TABLE. XI. CONCORDANCE OF 'TACTICS'

\begin{tabular}{|c|c|c|c|}
\hline \multicolumn{4}{|l|}{ TACTICS........................TF (2) } \\
\hline Context & word & context & line \\
\hline $\begin{array}{l}\text { said Squealer, was something } \\
\text { called }\end{array}$ & tactics & $\begin{array}{l}\text { He repeated a } \\
\text { number of }\end{array}$ & 152 \\
\hline $\begin{array}{l}\text { number of times, "Tactics, } \\
\text { comrades, }\end{array}$ & tactics & $\begin{array}{l}\text { !" skipping round and } \\
\text { whisking }\end{array}$ & 152 \\
\hline
\end{tabular}

TABLE. XII. CONCORDANCE OF 'EQUAL'

\begin{tabular}{|l|l|l|l|}
\hline \multicolumn{5}{|l|}{ EQUAL................TF (8) } & word & context & line \\
\hline Context & equal & $\begin{array}{l}\text {. ?And now, } \\
\text { comrades, I will }\end{array}$ & 138 \\
\hline other animal. All animals are & equal & $\begin{array}{l}\text {. It was very neatly } \\
\text { written }\end{array}$ & 364 \\
\hline animal. All animals are &
\end{tabular}

TABLE. XIII. CONCORDANCE OF 'BROTHERS'

\begin{tabular}{|l|l|l|l|}
\hline \multicolumn{2}{|l|}{ BROTHERS........................TF (1) } & line \\
\hline Context & word & context & 19 \\
\hline or simple, we are all & brothers & . No animal must ever kill & 19 \\
\hline
\end{tabular}

